\title{
Comparative analysis of anatomy and micro-densitometry of the growth rings of hardwoods and conifers, with emphasis on dendrochronology
}

\author{
Análise comparativa da anatomia e microdensitometria dos anéis de \\ crescimento de folhosas e de coníferas, com ênfase à dendrocronologia
}

\author{
Alisson Rangel Albuquerque ${ }^{1}$, Vinícius Resende de Castro² ${ }^{2}$ Moisés Silveira Lobão ${ }^{3}$, \\ Camila Sarto $^{4}$, Mario Tomazello Filho ${ }^{5}$ e Fernanda Trisltz Perassolo Guedes ${ }^{6}$
}

\begin{abstract}
Resumo
A sazonalidade climática induz variações na atividade do meristema cambial, refletindo em alterações significativas na estrutura anatômica do lenho e na formação dos anéis de crescimento no tronco das árvores. No presente trabalho foram selecionadas amostras de madeira de 17 espécies da Xiloteca do Laboratório de Anatomia e Identificação de Madeiras, Departamento de Ciências Florestais, caracterizando a estrutura anatômica macro e microscópica do lenho e a sua análise por densitometria de raios $\mathrm{X}$. As características anatômicas do lenho, com ênfase aos anéis de crescimento, indicaram as espécies arbóreas com maior potencial para os estudos de dendrocronologia, com destaque às da família Fabaceae-Caesalpinioideae. Com a densitometria de raios $\mathrm{X}$ obteve-se o perfil da densidade aparente do lenho e a delimitação do limite dos anéis de crescimento. Neste trabalho é enfatizada a importância da aplicação conjunta da anatomia da madeira e da densitometria de raios $\mathrm{X}$ como suporte para a dendrocronologia de árvores de espécies tropicais e subtropicais visando determinar a sua idade e taxa de crescimento, bem como para a sua caracterização tecnológica e manejo florestal sustentável.
\end{abstract}

Palavras-chave: Raios X, identificação de espécies, anatomia ecológica.

\begin{abstract}
The seasonal climate induces variations in the activity of cambial meristem reflecting in significant changes in the wood anatomical structure and formation of the growth rings. In this study wood samples of 17 species were selected from the Wood Collection of the Anatomy and Wood Identification Laboratory, Department of Forest Sciences, featuring its macro and microscopic anatomical wood structure and the analysis by X-ray densitometry. The wood anatomical characteristics, with emphasis on the growth rings, indicated the tree species with the greatest potential for dendrochronology, especially those of the Family Fabaceae-Caesalpinioideae. A wood density profile and the delimitation of the growth rings boundaries were obtained by X-ray densitometry. This paper emphasized the importance of joint application of wood anatomy and X-ray densitometry as support to dendrochronology of tropical and subtropical tree species in order to determine their age and growth rate, their technological characterization and sustainable forest management.
\end{abstract}

Keywords: X-ray, species identification, ecological anatomy

\footnotetext{
${ }^{1}$ Assistant Professor of the Department of Natural Sciences and Technology. UEPA - Universidade do Estado do Pará. Av, Hiléia, s/n - Agrópolis do INCRA - bairro Amapá - 68503 -120 - Marabá, PA, Brasil. PhD student in the Graduate Program in Forest Resources. USP - Universidade de São Paulo / ESALQ - Escola Superior de Agricultura "Luiz de Queiroz". Av. Avenida Páduas Dias, 11 Independência, 13418-900 - Piracicaba, SP, Brasil. E-mail: alissonrangel@uepa.br.

2Adjunct Professor at Department of Forest Science. UFV - Universidade Federal de Viçosa. Purdue avenue, s/n - 36570900 - Viçosa, MG, Brasil. E-mail: vinicius.castro@ufv.br.

${ }^{3}$ Adjunct Professor. UFAC - Universidade Federal do Acre / Center of Biological Sciences and Nature. Rod. 364, Km 04, Rio Branco, AC, Brasil. E-mail: moises lobao@yahoo.com.br.

${ }^{4} \mathrm{PhD}$ student in Graduate Program in Forest Resources, USP - Universidade de São Paulo / ESALQ - Escola Superior de Agricultura "Luiz de Queiroz". Av. Avenida Páduas Dias, 11 Independência, 13418-900 - Piracicaba, SP, Brasil. E-mail: sarto.camila@hotmail.com.

${ }^{5}$ Full Professor on Department of Forest Sciences. USP - Universidade de São Paulo / ESALQ - Escola Superior de Agricultura "Luiz de Queiroz". Av. Avenida Páduas Dias, 11 Independência, 13418-900 - Piracicaba, SP, Brasil. E-mail: mtomazel@esalq.usp.br.

${ }^{6}$ Pós-Doctoral at Department of Forest Science. USP - Universidade de São Paulo / ESALQ - Escola Superior de Agricultura "Luiz de Queiroz". Páduas Dias, 11 - 13418-900 - Piracicaba, SP, Brasil. E-mail: ftpguedes@gmail.com.
}

Sci. For., Piracicaba, v. 44, n. 111, p. 595-640, set. 2016 DOI: dx.doi.org/10.18671/scifor.v44n111.06 
Albuquerque et al. - Comparative analysis of anatomy and microdensitometry

of the growth rings of hardwoods and conifers, with emphasis on dendrochronology

\section{INTRODUCTION}

The seasonal variability of the temperature and precipitation affect the cambium activity and induces the formation of distinct growth rings in numerous tropical and subtropical species. In hardwood tree species the activity of the cambial meristem is usually related to the growth ring width, parenchyma bands and diameter and distribution of vessels; in conifers with tracheid length, wall thickness and diameter. The growth rings identified in tropical hardwood tree species presented distinct wood anatomical structure from those occurring in temperate climate, as a result of the genetic and adaptation features as well as due to the magnitude of climatic differences between the growing seasons (OLIVEIRA et al., 2007; CALLADO et al., 2013, 2014).

In tropical tree species, the main climatic variable inducing cambial seasonality is the rainfall distribution, in relation to the temperature, throughout the growing period; temperate hardwood trees are strongly influenced by temperature, precipitation, and photoperiod which play significant effect on meristem dormancy at the autumn-winter (JACOBY, 1989; SCHWEINGRUBER, 1996). While in temperate tree species the growth rings presented greater visibility and distinctness, in tropical hardwoods an accurate preparation of wood surface and detailed analysis of the anatomical structure is required, prior to the application of the classic methodologies of dendrochronology, seeking to date trees and determine the annual growth rate (ROIG, 2000; PALERMO et al., 2002).

More recently, wood X-ray densitometry has been applied as a useful and complementary methodology facilitating the delimitation and measurement of growth rings in several temperate, tropical and subtropical tree species due to the differentiated attenuation of X-rays through the wood tissues (MOTHE et al., 1998; KOUBAA, et al., 2002; LOBÃO, 2011). Among the scientific studies the methodology has preferably been applied for coniferous, broadleaves and introduced tree species, such as araucaria (WEHR; TOMAZELLO FILHO, 2000), pinus (FERREIRA; TOMAZELLO FILHO, 2009; CASTRO et al., 2014) and eucalyptus trees (TOMAZELLO FILHO et al., 2008; OLIVEIRA et al., 2012 KNAPIC et al., 2014).

Considering these aspects this paper aims at a comparative characterization of the growth rings of seventeen tropical and subtropical forest species by their anatomical structure and by X-ray densitometry as a subsidy for research on dendrochronology, also applied as a tool to evaluate and reconstruct the trunk diameter of the tree species aiming at sustainable forest management and to predict the wood quality.

\section{MATERIAL AND METHODS}

Tree species: in this work wood samples of 17 tree species were selected (at least 3 wood samples/species) from the Wood Collection of the Wood Anatomy and Identification Laboratory/Department of Forest Sciences/ESALQ (Table 1).

Wood macroscopic and characterization: the wood samples were cut and oriented in the three basic planes of study. Subsequently, the wood cross section was polished with steel blades in a sliding microtome, followed by the wood and growth ring anatomical characterization under a stereoscopic microscope (6-20X) according to IBAMA (1991).

Wood microscopic characterization: wood samples $(15 \times 10 \times 10 \mathrm{~mm})$ were saturated in water and thin cross sections $(15 \mu \mathrm{m})$ were cut in a sliding microtome and mounted on permanent slides for analysis and description of the microscopic anatomical structure according to IAWA (IAWA, 1989).

Wood X-ray densitometry characterization: a wood radial section of the wood samples was cut, glued on a woody support, cut in cross sections ( $2 \mathrm{~mm}$ thick) by a dual-parallel circular saw and acclimatized $\left(20^{\circ} \mathrm{C}, 60 \% \mathrm{RH}, 24 \mathrm{~h}\right)$. The wood samples were adjusted in metal support and transferred to radiation chamber of the X-ray equipment (Quintek Measurement Systems, USA, Figure 1A) followed by the calibration and continuous scanned by a collimated X-ray beam (Figure 1B, C). The X-ray intensity through the wood sample is transformed into bulk density by QMS software, building the radial wood density profile observed on the monitor screen. The radial values of the wood bulk density originate a DAT file (wood density values each $40 \mu \mathrm{m}$ ) and read by Excel software generating the wood radial density profile (Figure 1D, E) (TOMAZELLO FILHO et al., 2008; CASTRO et al., 2014). 
Tabela 1. Anatomical and densitometry characteristics of the growth rings of woody forest species

Table 1. Características anatômicas e densitométricas dos anéis de crescimento do lenho das espécies florestais.

\begin{tabular}{|c|c|c|c|c|c|c|c|c|}
\hline \multirow{3}{*}{ No. } & \multirow{3}{*}{ Scientific name } & \multirow{3}{*}{ Family } & \multicolumn{6}{|c|}{ Characteristics } \\
\hline & & & \multicolumn{5}{|c|}{ Anatomical } & \multirow{2}{*}{$\begin{array}{c}\text { Densitometric } \\
\text { Profile }\end{array}$} \\
\hline & & & D & $\mathbf{P}$ & WT & MP & DP & \\
\hline 1 & Astronium graveoleons & Anacardiaceae & A & 3 & 3 & 1 & 1 & 1 \\
\hline 2 & Balfourodendron riedelianum & Rutaceae & B & 3 & 2 & 3 & 3 & 5 \\
\hline 3 & Caesalpinia leiostachya & Fabaceae - Caesalpinioideae & B & 3 & 3 & 3 & 2 & 3 \\
\hline 4 & Cariniana legalis & Lecythidaceae & B & 3 & 3 & 3 & 2 & 3 \\
\hline 5 & Cedrela odorata & Meliaceae & $A$ & 2 & 1 & 1 & 1 & 1 \\
\hline 6 & Copaífera langsdorffii & Fabaceae Caesalpinioideae & $A$ & 3 & 2 & 3 & 1 & 2 \\
\hline 7 & Eucalyptus cloeziana & Myrtaceae & $\mathrm{B}$ & 3 & 2 & 3 & 2 & 4 \\
\hline 8 & Hymenaea courbaril & Fabaceae - Caesalpinioideae & $A$ & 3 & 1 & 1 & 1 & 1 \\
\hline 9 & Joannesia princeps & Euphorbiaceae & B & 3 & 2 & 3 & 2 & 4 \\
\hline 10 & Laurus nobilis & Lauraceae & $A$ & 3 & 3 & 3 & 1 & 3 \\
\hline 11 & Pterocarpus violaceus & Fabaceae Faboideae & B & 3 & 3 & 3 & 2 & 3 \\
\hline 12 & Schizolobium parahyba var. parahyba & Fabaceae - Caesalpinoideae & $A$ & 3 & 2 & 1 & 1 & 3 \\
\hline 13 & Tabebuia serratifolia & Bignoniaceae & B & 3 & 3 & 3 & 2 & 4 \\
\hline 14 & Tectona grandis & Verbenaceae & $A$ & 1 & 1 & 1 & 1 & 1 \\
\hline 15 & Zeyheria tuberculosa & Bignoniaceae & B & 3 & 2 & 3 & 2 & 4 \\
\hline 16 & Araucária angustifólia & Araucariaceae & $A$ & 3 & 3 & 3 & 1 & 3 \\
\hline 17 & Pinus sp. & Pinaceae & $A$ & 3 & 3 & 3 & 1 & 3 \\
\hline
\end{tabular}

Legend:Distinction(D): distinct(A); poorlydistinct(B); Porosity(P): porous ring(I), semi-porousring(2), diffuseorabsentpores(3); Wallthickness (WT): thin to thick (I ), thick (2), fibrous zone (3); Marginal parenchyma (MP): continuous (I), discontinuous (2), absent (3); Dendrochronology potential (DP): $\operatorname{good}(\mathrm{I})$, difficult(2), notpossible(3); DensitometryProfile:thereisanabruptdropindensityattheringlimit(I), thereisagradualdecreaseintheringdensity (2) Legenda: distinto (A); pouco distinto (B); porosidade (P): anel poroso (I), anel semi-poroso (2), poros difusos ou ausentes (3); espessura da parede (GP): fina para grossa (I), grossa (2), zona fibrosa (3); parênquima marginal (PM): contínuo (I), descontínuo (2), ausente (3); potencial dendrocronológico (PD): bom (I), com dificuldade (2), não possível (3); perfil densitométrico: há queda abrupta da densidade no limite do anel (I), há queda gradual na densidade do anel (2)
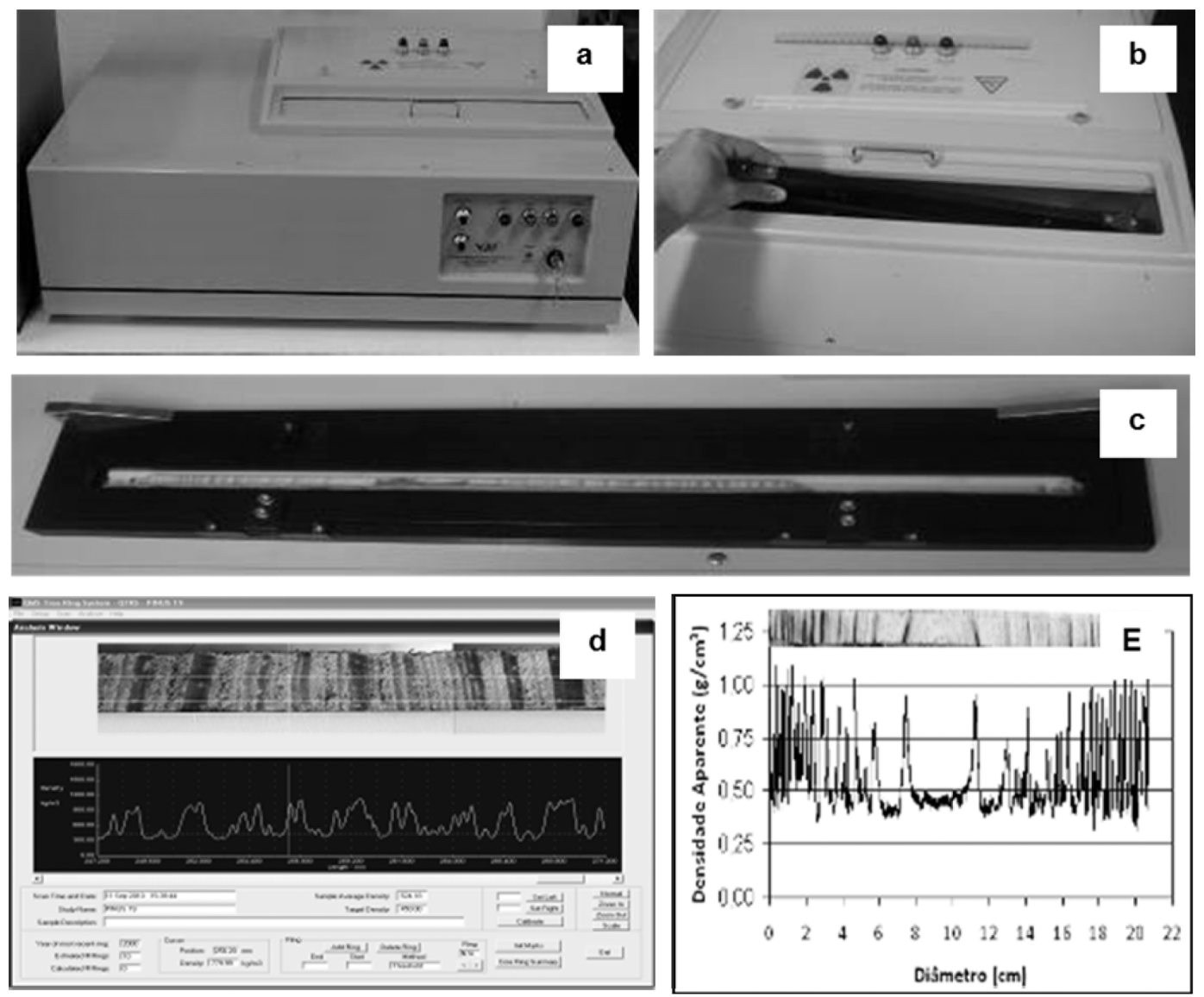

Figura 1. Tree-ring characterization of Pinus sp. (a) X-ray equipment; (b-c) sample support and insertion into the compartment; (d-e) wood cross section/ wood radial density profile.

Figure 1. Caracterização dos anéis de crescimento de Pinus sp. (a) equipamento de raios $X ;$ (b-c) suporte metálico- amostra do lenho e inserção no compartimento; (d-e) seção transversal do lenho/perfil radial de densidade. 
Albuquerque et al. - Comparative analysis of anatomy and microdensitometry

of the growth rings of hardwoods and conifers, with emphasis on dendrochronology

\section{RESULTS AND DISCUSSION}

\section{Wood macro and microscopic characterization}

The wood anatomical and X-ray densitometry features of the growth rings of broadleaf and conifer species, as well the summarized data of each species, are presented in the Figures 2, 3 and Table 2.

Concerning the growth ring distinction parameter (D) the results showed nine species with distinct rings and eight species with slightly distinct rings. In terms of the vessel porosity $(\mathrm{P})$, only Tectona grandis (teak) (Figure 2-14) presented porous rings and Cedrela odorata (cedar) (Figure 2-5) semi-porous rings delimitated by marginal parenchyma. The wood of these two species had higher vessel concentration with larger diameter formed at the beginning of the vegetative period of the trees. Cedrela odorata (Meliaceae) is a well known tree species with the cambial activity, formation of tree-rings and growth dynamics presented by Dünisch et al., (2002), Marcati et al., (2006) and Lobão (2011); related to climatic signals (ANDREACCI et al., 2014); to determine the periodicity and trunk growth increments (BOTOSSO et al., 2000), for dendrochronology (TOMAZELLO FILHO et al., 2000, 2001) and dendro-ecological analysis (ALVES; ANGYALOSSY-ALFONSO, 2000; DÜNISCH et al., 2003). Similarly, the growth rings formed in Tectona grandis trees constitute a valuable tool applied to numerous research abroad and in Brazil correlating with the climatic variables (PUMIJUMNONG et al., 1995; RAM et al., 2008; UGOLINO et al, 2014), as well with the wood quality (CASTRO et al., 2011).

The remaining tree species showed diffuse or absent porosity. Related to cell wall thickness (WT), three species presented wood with a thin to thick cell wall; six species had thick walls and six species with tree-rings characterized by a darker fibrous zone similar to latewood. Within seventeen species only five had wood with continuous bands of marginal parenchyma.

As for wood anatomical features of tree species, Astronium graveolens (Anacardiaceae) (Figure 2-1) is characterized by an increase of vessel frequency and diameter reduction and a layer of marginal parenchyma in the boundary of the late/early wood transition delimiting the tree-ring presenting a dendrochronological potential, corroborating with the results of Cury (2002), Tomazello Filho et al. (2004) and Trevizor (2011). Lisi et al. (2008) evaluated the tree-ring formation, radial increment periodicity, and phenology; and Alves and Angyalossy-Alfonso (2000) observed growth rings as ecological trends in the wood anatomy of this species.

Laurus nobilis (Lauraceae) (Figure 2-11) had wood characterized by growth rings with differentiation in the vessel frequency and the latewood of the growth layer is not totally distinct and indicated by darker tangential fibrous zone, according to Carlquist (1980) and Lourfy (2009).

The wood of Copaifera langsdorffii (Fabaceae-Caesalpinoideae) (Figure 2-7) is characterized by growth rings delimited by a clear series of oil-resin ducts and marginal parenchyma presenting high potential for dendrochronology, also observed by Marcati et al., (2001), Cury (2002), Tomazello Filho et al. (2004), Marcati et al., (2006), Trevizor (2011), Sonsin et al., (2012) and Longui et al., (2014). The tree-ring formation, radial increment periodicity, phenology and ecological trends of wood anatomy were characterized by Alves and Angyalossy-Alfonso (2000), Lisi et al. (2008) and Costa et al., (2015).

Caesalpinia leiosthachya (Fabaceae-Caesalpinoideae) (Figure 2-3) presented distinct growth rings with diffuse porosity and continuous marginal parenchyma, also observed by Tomazello Filho et al. (2004) and Alves (2010); including the evaluation of tree-ring formation, wood ecology radial increment periodicity, and phenology of this tree species by Alves and Angyalossy-Alfonso (2000) and Lisi et al. (2008).

The wood anatomy of Handroanthus (Tabebuia serratifolia) trees (Bignoniaceae) (Figure 2-8) are similar to that described by Trevizor (2011); the ecological wood anatomy by Alves and Angyalossy-Alfonso (2000); and tree-ring formation, radial increment and phenology were detailed by Lisi et al., (2008). The tree-ring and wood anatomy of Zeyheria tuberculosa (Bignoniaceae) (Figure 2-15) were also described by Alves (2010) and the tree-ring, increment periodicity and phenology were presented by Lisi et al., (2008). The growth layers of Pterocarpus violaceus (Fabaceae-Faboideae) (Figure 2-12) are defined by parenchyma cells and in Joannesia princeps (Euphorbiaceae) (Figure 2-10) are distinct and delimited by darker fibrous zones and the ecological trends in the wood anatomy of these species (growth rings and vessels) were reported by Alves and Angyalossy-Alfonso (2000) and Costa et al., (2015). 
Balfourodendron riadelianum (Rutaceae) (Figure 2-2) shows peculiar reticulate axial parenchyma cells, with poorly distinct growth rings characterized by the distance of parenchyma bands, typically thinner and closer in the end of growing period. The wood ecological trends were considered by Alves and Angyalossy-Alfonso (2000) and Lisi et al. (2008) described the tree-ring formation, trunk increment periodicity and the phenology of this tree species.

Schizolobium parahyba var. parahyba (Fabaceae-Caesalpinoideae) (Figure 2-13) has distinct growth rings, delimited by a fibrous zone (thickening of the fiber wall, flattening of radial wall) and marginal parenchyma band (CURY, 2002, TOMAZELLO FILHO et al., 2004). Several authors, used tree-rings of this tree species for detection the seasonal wood development (MARCATI et al., 2008); mortality tree diagnosis (CALLADO; GUIMARÃES, 2010), phenology and cambial activity and their relationship with wood formation and quality (LISI et al., 2008; LOBÃO, 2011; LOBÃO et al., 2012; COSTA et al., 2015) and dendrochronological issues (LATORRACA et al., 2015).

The trees of Hymenaea sp. (Fabaceae-Caesalpinioideae) (Figure 2-9) presented distinct growth rings divided by marginal parenchyma bands and vessels obstructed by amorphous and crystalline substances, described by Cury (2002) and Trevizor (2011). The tree-ring radiocarbon measurements define the trunk growth rates of the trees in Amazon forests (MOZETO et al., 1988), as well as the wood ecological characteristics. The trunk growth periodicity and sustainable cycles of trees cutting (LUCHI, 1998; HUAMAN-CALDERÓN, 2011) and the wood ecological trends, as well as the tree-ring formation related to the phenology this tree species were studied by Alves and Angyallosy-Alfonso (2000) and Lisi et al. (2008).

Cariniana sp. (Lecythidaceae) (Figure 2-4) presented a homogeneous reticulate parenchyma resulting in a poorly distinct growth ring characterized by thinner and closer parenchyma lines at the end of the growth period, as well as a scarcity of vessels, as reported by Mainieri and Chimelo (1989) and Tomazello Filho et al. (2004). Also, Alves and Angyalossy-Alfonso (2000) and Lisi et al. (2008) reported the wood ecological trends, tree-ring formation, radial increment periodicity and phenology of this tree species.

Regarding all species of tree species analyzed, the conifers Araucaria angustifolia (Araucariaceae) (Figure 3-1, Tabela 2) and Pinus sp. (Pinaceae) (Figure 3-2, Tabela 2), are well known to have the tree-rings distinct and formed by early-latewood, with eventual formation of false growth rings. The scientific literature that reports the anatomical structure and application of the tree-rings of these two species of conifers is significant (WEHR; TOMAZELLO FILHO, 2000; MEDEIROS et al., 2008; FERREIRA; TOMAZELLO FILHO, 2009; OLIVEIRA, 2007; OLIVEIRA et al., 2009; CASTRO et al., 2014).

Within the list of the species, nine showed potential for dendrochronology while the remaining eight species require the application of complementary methodologies. Among the available techniques, the more common are radiocarbon $\left({ }^{14} \mathrm{C}\right)$ used successfully by Lisi et al., (2001), Kromer (2009) and Santos et al., (2015) in dating tree-rings of araucaria trees, and "Mariaux window" applied by Luchi (1998) in dating the induced scars - due to response of cambial cells injuries - in order to determine the annuity of tree-rings of Hymenaea courbaril trees.

It was found that $53 \%$ of the species anatomically studied in the present study have potential for further dendro-cronological study, especially species representative of the Fabaceae-Caesalpinioideae family (Table 2). Alves and Angyalossy-Alfonso (2000), in order to evaluate the ecological trends in the wood anatomy of Brazilian tropical species, observed the presence of growth rings in $48 \%$ of the species studied. Also, Mainieri et al. (1983) detected growth rings in 35\% of the 300 wood species analyzed. The application of complementary technique, as X-rays densitometry is recommended and useful to determine the growth ring boundaries as complementary to the wood anatomy features.

\section{Wood X-ray densitometry characterization}

X-ray densitometry is an analytical technique that was developed in the early 1970 s by Parker analyzing Picea engelmannii trees in Canada, and pioneered by Polge in the late 1960's and the significant relationships between density and climate (dendroclimatology) were evident (POLGE, 1970, 1978; PARKER; HENOCH, 1971, WHITE, 2010). Similarly, for several forest tree species of temperate climate, such as Quercus spp and Picea mariana, the X-ray densitometry has been applied in defining the boundaries of the annual tree rings, considering its relationship with the density of the early-latewood and characterization of transition juvenile-mature wood (MOTHE et al 1998; KOUBAA et al, 2002; ALTEYRAC et al., 2006).

Sci. For., Piracicaba, v. 44, n. 111, p. 595-610, set. 2016 DOI: dx.doi.org/10.18671/scifor.v44n111.06 


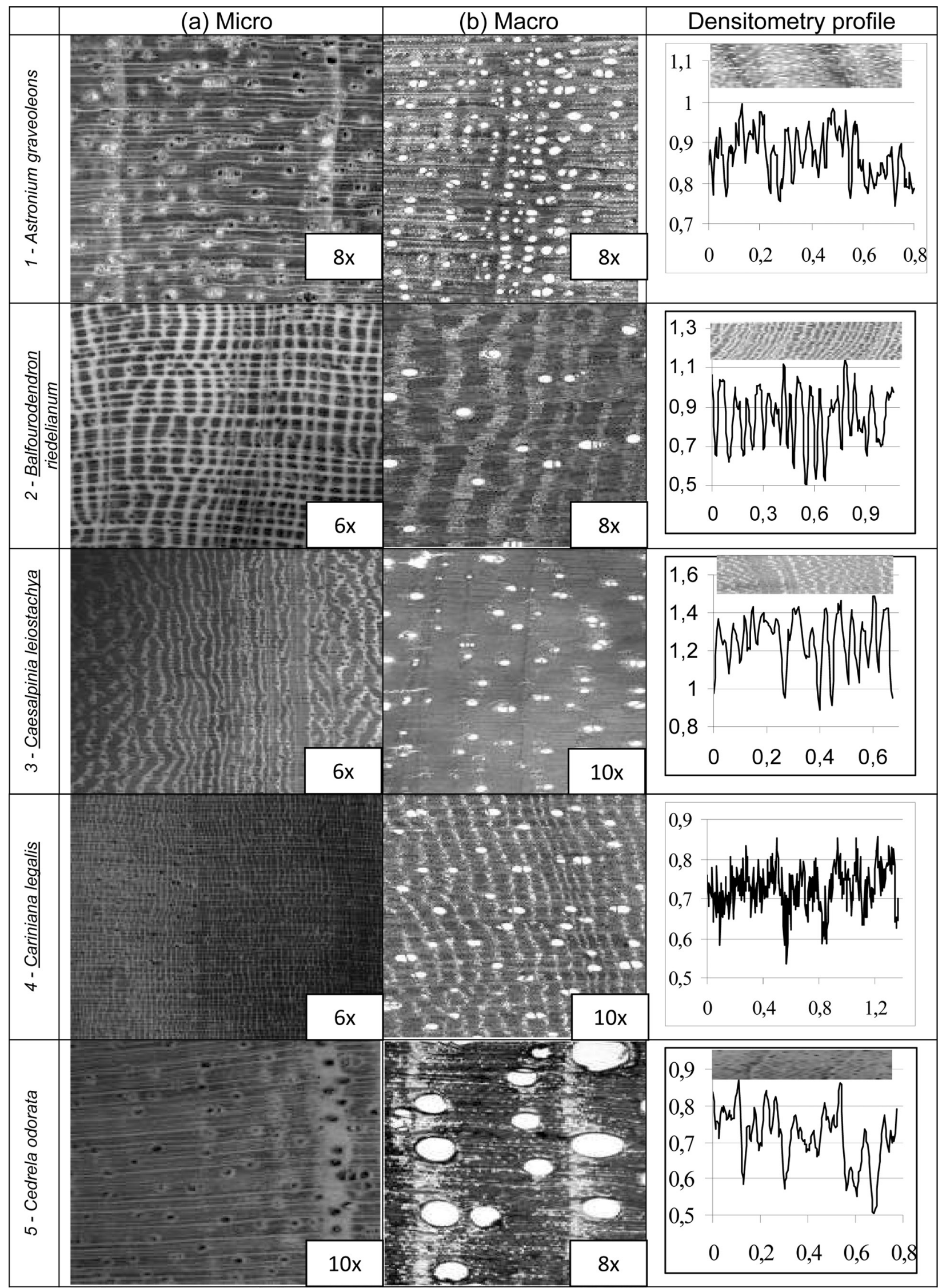

Figura 2. Images of micro, macro and densitometry profile of the wood of the 15 species studied. The images were obtained from wood transversely oriented: (a) Macro Image (macroscopic), obtained directly from the sample using a stereoscopic microscope and (b) Micro Image (microscopic), histological section mounted on a permanent slide and observed under a microscope incident light.

Figure 2. Imagens micro, macro e perfil densitométrico do lenho das 15 espécies estudadas. As imagens foram obtidas a partir lenho orientado transversalmente: (a) Imagem Macro (macroscópica), obtida diretamente da amostra usando um microscópio estereoscópico e (b) Imagem Micro (microscópica), corte histológico montado em uma lâmina permanente, e observado sob um microscópio de luz incidente. 


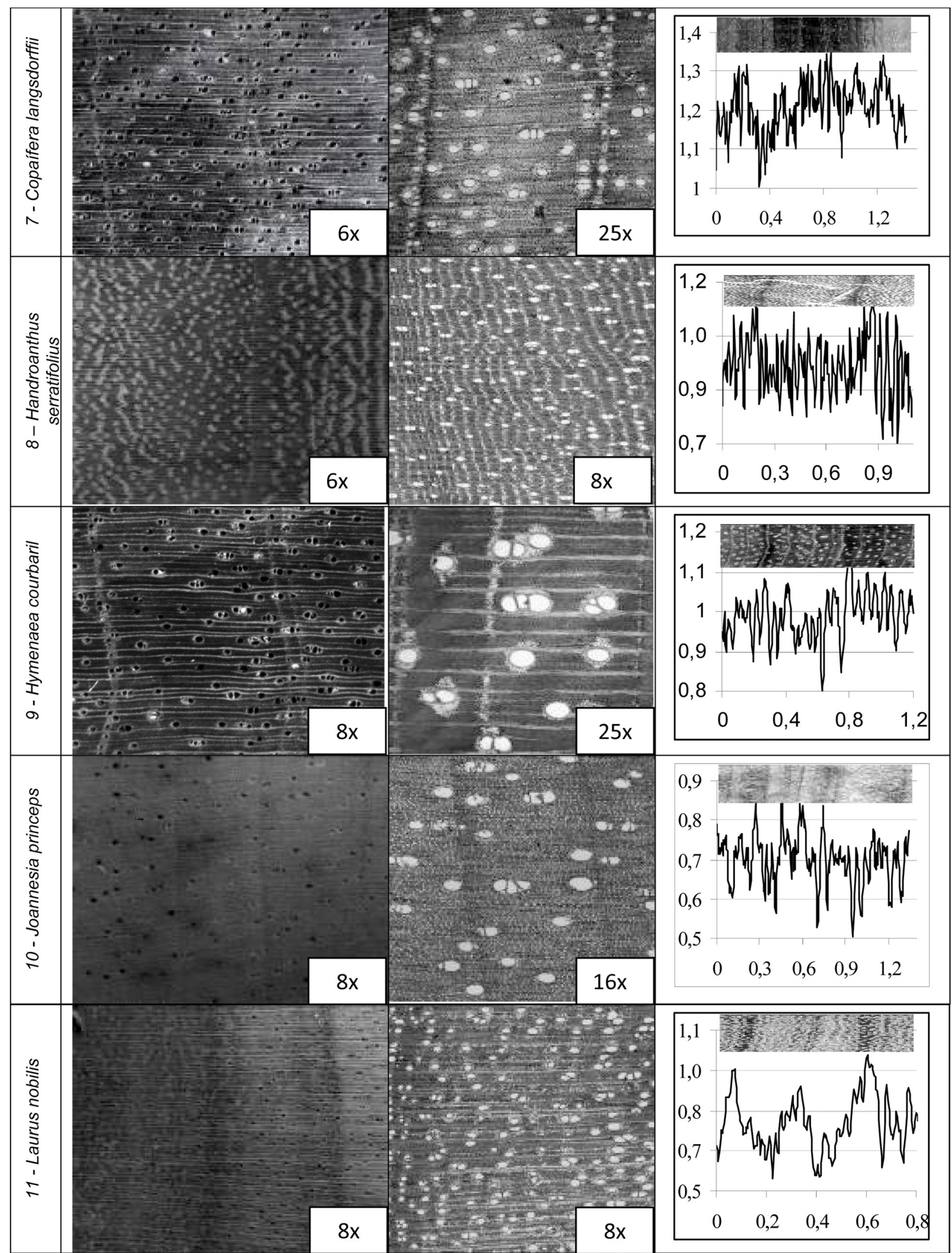

Figura 2 - Continuação. Images of micro, macro and densitometry profile of the wood of the 15 species studied. The images were obtained from wood transversely oriented: (a) Macro Image (macroscopic), obtained directly from the sample using a stereoscopic microscope and (b) Micro Image (microscopic), histological section mounted on a permanent slide and observed under a microscope incident light.

Figure 2 - Continuação. Imagens micro, macro e perfil densitométrico do lenho das 15 espécies estudadas. As imagens foram obtidas a partir lenho orientado transversalmente: (a) Imagem Macro (macroscópica), obtida diretamente da amostra usando um microscópio estereoscópico e (b) Imagem Micro (microscópica), corte histológico montado em uma lâmina permanente, e observado sob um microscópio de luz incidente. 


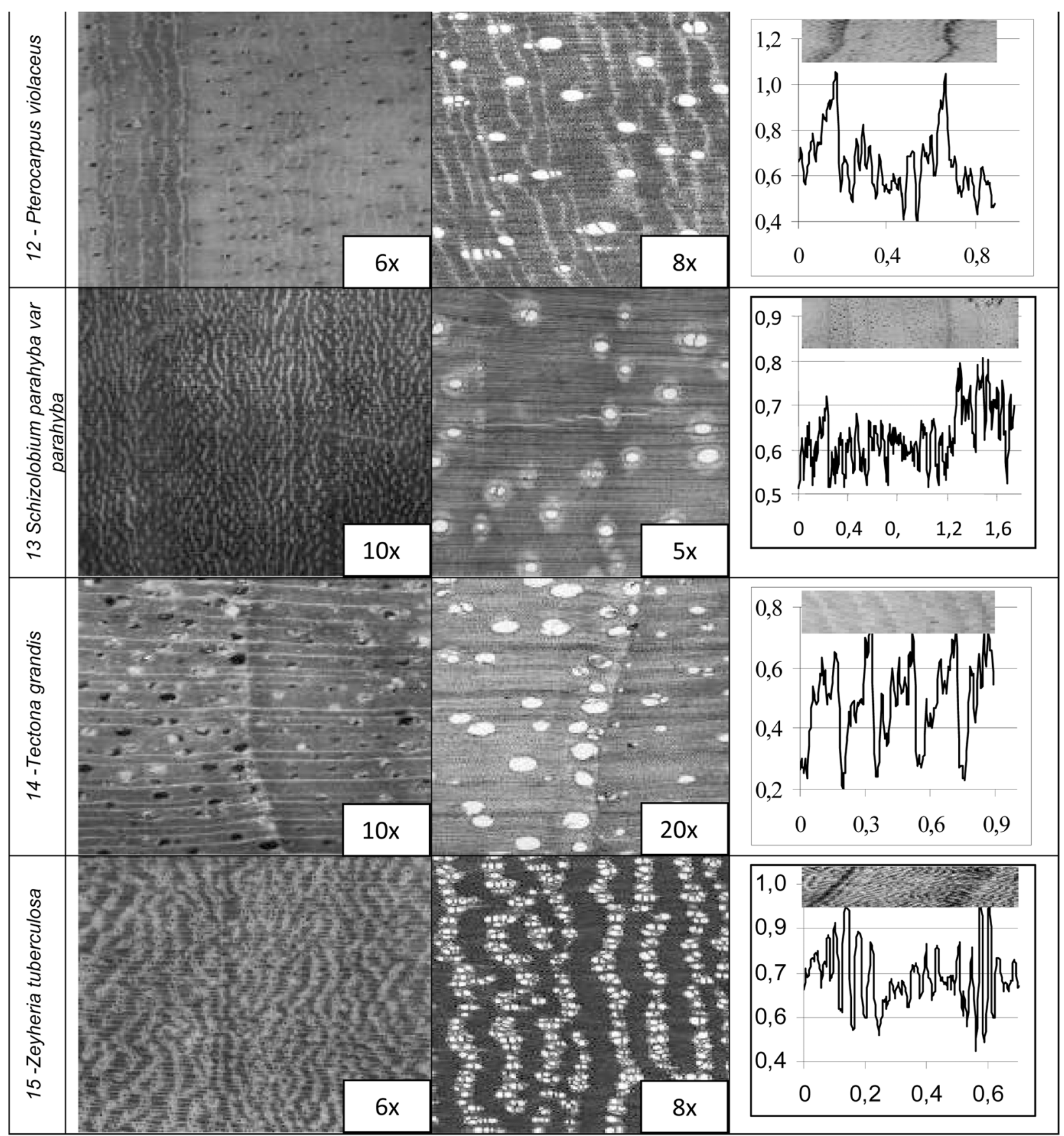

Figura 2 - Continuação. Images of micro, macro and densitometry profile of the wood of the 15 species studied. The images were obtained from wood transversely oriented: (a) Macro Image (macroscopic), obtained directly from the sample using a stereoscopic microscope and (b) Micro Image (microscopic), histological section mounted on a permanent slide and observed under a microscope incident light.

Figure 2 - Continuação. Imagens micro, macro e perfil densitométrico do lenho das 15 espécies estudadas. As imagens foram obtidas a partir lenho orientado transversalmente: (a) Imagem Macro (macroscópica), obtida diretamente da amostra usando um microscópio estereoscópico e (b) Imagem Micro (microscópica), corte histológico montado em uma lâmina permanente, e observado sob um microscópio de luz incidente.

Wood X-ray densitometry technique was initially applied in Brazil aiming at the determination of the tree ring characteristics and wood density profile of Pinus taeda trees by Amaral and Tomazello (TOMAZELLO FILHO et al, 2008). After the initial and successful results, X-ray densitometry was applied to other coniferous species by several authors analyzing the structure of the growth rings of Araucaria angustifolia trees allowed to correlated with wood anatomy and quality, as well as to improve the ${ }^{14} \mathrm{C}$ calibration curve for the Southern Hemisphere (WEHR; TOMAZELLO FILHO, 2000; SANTOS et al., 2015); also in Araucaria columnaris trees as a lead indicator of environmental monitoring (MEDEIROS et al., 2008). The wood density profile of Araucaria angustifolia (Figure 3-1, Table 2) is similar to that described by the referenced authors, reflecting the anatomical structure of 
early $\left(0,5 \mathrm{~g} / \mathrm{cm}^{3}\right)$ and latewood $\left(0,75 \mathrm{~g} / \mathrm{cm}^{3}\right)$ and allowing their differentiation, as well as the perfect definition and mensuration of the annual growth increment.

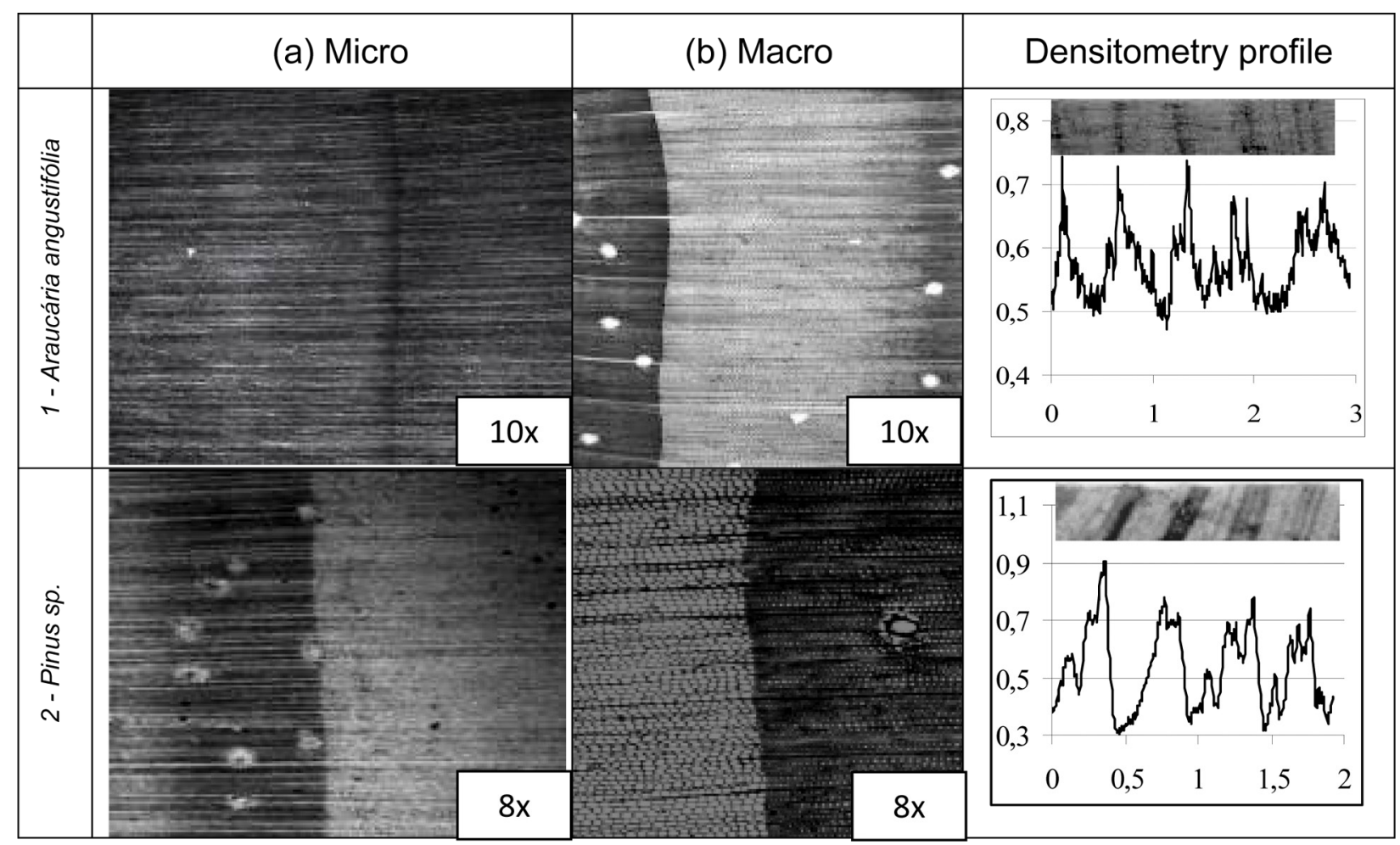

Figura 3. Micro, macro and densitometry profile images of the 2 conifer species studied. The images were obtained from the transverse plane of the wood of this species, with the (a) Macro (macroscopic) directly from the specimen using a stereoscopic microscope and (b) Micro (Microscopic) by histological slices, and observed under a incident light microscope.

Figure 3. Imagens micro, macro e perfil densitométrico do lenho das 15 espécies estudadas. As imagens foram obtidas a partir lenho orientado transversalmente: (a) Imagem Macro (macroscópica), obtida diretamente da amostra usando um microscópio estereoscópico e (b) Imagem Micro (microscópica), corte histológico montado em uma lâmina permanente, e observado sob um microscópio de luz incidente.

Similarly, for pine trees (Figure 3-2, Table 2) the density radial profile is equivalent to that described for Caribbean pine trees by several authors (FERREIRA; TOMAZELLO FILHO, 2009; CASTRO, 2011; CASTRO et al., 2014) and for the Araucaria trees which are composed of wood tissues with high contrast in density due to their anatomical structure, with early wood $\left(0,3 \mathrm{~g} / \mathrm{cm}^{3}\right)$ sequenced by latewood $\left(0,9 \mathrm{~g} / \mathrm{cm}^{3}\right)$ of the same annual growth ring.

When comparing with temperate tree species, the X-ray densitometry was less often applied in tropical and subtropical broadleaf native trees from natural populations and plantations. In the specialized literature the families Meliaceae, Fabaceae-Caesalpinoideae, Lecythidaceae could be mentioned; while among exotic species the families Myrtaceae, Lamiaceae and Verbenaceae.

Concerning the Meliaceae family, their representative species of Swietenia macrophylla, Cedrela odorata and C. fissilis were analyzed with respect to the tree rings width and wood density variation, dendrochronology, cambium activity and sustainable forest management (ALVARADO et al., 2010; LOBÃO, 2011, SCHIPPER-GUEROVICH, 2011). The wood density profile of Cedrela odorata (Figure $2-5$, Table 2) is not comparable with that observed in the conifers wood; the main characteristic is the abrupt drop of wood density (equivalent to the marginal parenchyma and semi-ring porous, representing the earlywood with $0.5 \mathrm{~g} / \mathrm{cm}^{3}$ ) followed by a gradual increase of density (equivalent to less vessel frequency and thicker fiber cell wall, representing the latewood with $0.9 \mathrm{~g} / \mathrm{cm}^{3}$ ). The typical variation of wood density in Cedrela and many other broadleaves is due to the response of the variation of vessels frequency and diameter.

Among the Lamiaceae family, Tectona grandis trees are commonly studied by X-ray densitometry in order to discriminate and characterize the juvenile and adult wood (BHAT et al., 2001; CASTRO, 2011; CASTRO et al., 2011); to analyze the retention and penetration of CCA in teakwood fence posts (CHAGAS et al, 2015); the provenance effect on the tree ring structure (NOCETTI et al., 2011); wood density in relation to tissue proportions and growth of teak trees (RAHMAN et al, 2004) and 
visualization of tree-rings in three dimension using X-ray tomography (BULCKEA et al., 2014). The wood density profile of Tectona grandis (Figure 2-14, Table 2) is very similar to that described for Cedrela, with annual tree-rings bordered by early wood $\left(0.2 \mathrm{~g} / \mathrm{cm}^{3}\right)$ and latewood $\left(0.5 \mathrm{~g} / \mathrm{cm}^{3}\right)$.

With respect to the family Fabaceae-Caesalpinioideae, results applying the X-ray densitometry in Schizolobium parahyba var. amazonicum were found to characterize the tree-rings and wood density variability across the poles and, also, the wood quality (LOBÃO, 2011; LOBÃO et al., 2012). In the annual tree-rings of $S$. parahyba (Figure 2-13, Table 2$)$ the early wood $(0.5 \mathrm{~g} / \mathrm{cm} 3)$ is followed by the latewood $\left(0.8 \mathrm{~g} / \mathrm{cm}^{3}\right)$ with a distinct gradual increase of density due to the lower vessel diameter and frequency.

Concerning Hymenaea courbaril, tree-rings and wood density profiles were applied in dendrochronology and for sustainable forest management in the tropical Amazon forests of Madre de Dios, Peru (HUAMAN-CALDERÓN, 2011). The wood density profile of $H$. courbaril (Figure 2-9, Table 2) is typical of the hardwood with high density value due to their anatomical features, especially defined by the fine marginal parenchyma band $\left(0.8 \mathrm{~g} / \mathrm{cm}^{3}\right)$ delimiting the wood region of higher density $\left(1.1 \mathrm{~g} / \mathrm{cm}^{3}\right)$.

The family Lecythidaceae, represented by Cariniana legalis trees managed under different spacing, were scanned by X-ray densitometry which allowed to determine the tree-ring boundaries and perform a detailed evaluation of wood quality (OLIVEIRA, 2015). The wood density profile of C. legalis (Figure 2-4, Table 2) directly reflects its anatomical structure characterized by the formation of typical narrow bands of reticulate parenchyma, with minimum and maximum variations of 0.55 and $0.85 \mathrm{~g} / \mathrm{cm}^{3}$, respectively. In this tree species, the growth rings are more clearly typified by regions of fibrous areas, darker coloring and higher density.

The other studied tree species were not supported by bibliography in the literature relating to the correlation between the anatomy and the wood density profile. Among these species, Astronium graveoleons trees (Figure 2-1, Table 2) presented growth rings delimited by axial parenchyma bands reflecting a wood density profile defined by a sharp drop in density (parenchyma tissue, $0,7 \mathrm{~g} / \mathrm{cm}^{3}$ ) alternating with higher density (fibrous tissue, $1,0 \mathrm{~g} / \mathrm{cm}^{3}$ ). Also in Copaifera langsdorffii trees (Figure 2-7, Table 2) the same pattern of wood density profile was detected, with an alternation of lower density (marginal parenchyma associated with tangentially secretory canals, with $1.0 \mathrm{~g} / \mathrm{cm}^{3}$ ) and higher density (fibrous area, with $1.3 \mathrm{~g} / \mathrm{cm}^{3}$ ). In Balfourodendron riedelianum trees (Figure 2-2, Table 2 ) the sequence of fibers and parenchyma zones, typical of this species, was reflected in distinct alternation of the highest $\left(1.1 \mathrm{~g} / \mathrm{cm}^{3}\right)$ and lowest $\left(0.5 \mathrm{~g} / \mathrm{cm}^{3}\right)$ values of wood density. Zeyheria tuberculosa trees (Figure 2-15, Table 2) have a wood anatomical structure comparable to B. riedelianum wood with the main differences relating to the greater width of fibers $\left(0.95 \mathrm{~g} / \mathrm{cm}^{3}\right)$ and parenchyma $\left(0.5 \mathrm{~g} / \mathrm{cm}^{3}\right)$ zones. Similarly, Handroanthus (Tabebuia) serratifolia trees (Figure 2-8, Table 2) show similarity in their anatomy, with narrower fiber $\left(1.1 \mathrm{~g} / \mathrm{cm}^{3}\right)$ and parenchyma $\left(0.7 \mathrm{~g} / \mathrm{cm}^{3}\right)$ bands; and Caesalpinia leiostachya (Figure 2-3, Table 2) trees with growth ring boundary with longitudinal parenchyma $\left(0.9 \mathrm{~g} / \mathrm{cm}^{3}\right)$ and fiber zones $\left(1.4 \mathrm{~g} / \mathrm{cm}^{3}\right)$; Pterocarpus violaceus (Figure 2-12, Table 2) also presented a wood region with higher $\left(1.1 \mathrm{~g} / \mathrm{cm}^{3}\right)$ and lower $\left(0.4 \mathrm{~g} / \mathrm{cm}^{3}\right)$ density profile, related to their anatomical features, similar to the Joannesia princeps trees with density variation of 0.85 (latewood) and 0.50 (early wood) $\mathrm{g} / \mathrm{cm}^{3}$ (Figure 2-10, Table 2).

A similar methodology was also applied in Gmelina arborea trees, in the Verbenaceae family, from Costa Rica, aiming to obtain the wood density variation and tree ring demarcation (MOYA; TOMAZELLO FILHO, 2009). Concerning the Myrtaceae family, the X-ray densitometry has been used to characterize the wood features of Eucalyptus spp., as a non-destructive method (TOMAZELLO FILHO, et al., 2008); to correlate with the climatic variability (OLIVEIRA et al., 2011) and to determine the wood density variation as a parameter of wood quality and with potential for biomass production (KNAPIC et al. 2014).

In the specialized literature the association of the two methodologies provides and aggregates the evaluation of the wood anatomical characteristics and their physical properties (tree-ring density). This methodology is important, especially for tropical and subtropical species where, unlike the temperate, the growth rings are not clear. Thus, the work enables the development of a new research field applied in ecological anatomy, dendroclimatology, wood quality, sustainable forest management, etc. 


\section{CONCLUSIONS}

The results of the wood anatomical features of growth rings provided information concerning the tropical and subtropical tree species with higher potential for dendrochronological studies. The wood X-ray densitometry constitutes a complementary methodology allowing to apply the wood density profile - directly related to the wood anatomical features - to determine the growth ring boundaries. Among the families of broadleaves and conifers with the greatest potential were cited the Anacardiaceae, Araucariaceae, Fabaceae-Caesalpinoideae, Pinaceae, Lauraceae, Meliaceae and Verbenaceae. The wood anatomical and X-ray densitometry analyses are fundamental to dendrochronology applied to tropical and subtropical tree species and allowing their application in the sustainable forest management and evaluation of wood quality.

\section{REFERENCES}

ALTEYRAC, J.; CLOUTIER, A.; ZHANG, E. S. Y. Characterization of juvenile wood to mature wood transition age in black spruce (Picea mariana) at different stand densities and sampling heights. Wood Science and Technology, New York, v. 40, n. 2, p. 124-138, 2006.

ALVARADO, J. R.; TOMAZELLO FILHO, M.; POLLITO, P. A. Z.; LOBÃO, M. S. Variação da densidade do lenho e relação com a largura dos anéis de crescimento de árvores de mogno, Swietenia macrophylla, da floresta tropical amazônica do Peru. Scientia Forestalis, Piracicaba, v. 38, n. 86, p. 171-179, 2010.

ALVES, E. S.; ANGYALOSSY-ALFONSO, V. Ecological trends in the wood anatomy of some Brazilian species. 1. growth rings and vessels. IAWA Journal, Leiden, v. 21, p. 3-30, 2000.

ALVES, R. C. Elaboração de um atlas e de uma chave para identificação das principais madeiras comercializadas no estado do Espírito Santo. 2010. 55 p. Monografia (Engenheiro Industrial Madeireiro) Universidade Federal do Espírito Santo, Espírito Santo, 2010.

ANDREACCI, F.; BOTOSSO, P. C.; GALVÃO, F. Sinais climáticos em anéis de crescimento de Cedrela fissilis em diferentes tipologias de florestas ombrófilas do sul do Brasil. Floresta, Curitiba, v. 44, n. 2, p. 323-332, 2014.

BHAT, K. M.; PRIYA, P. B.; RUGMINI, P. Characterisation of juvenile wood in teak. Wood Science and Technology, New York, v. 34, n. 6, p. 517-532, 2001.

BOTOSSO, P. C.; VETTER, R. E.; TOMAZELLO FILHO, M. Periodicidade e taxa de crescimento de árvores de Cedrela odorata, Calophyllum angulare e Eperua bijuga. In: ROIG, F. A. (Org.). Dendrocronologia en America Latina. Mendonza: EDIUNC, 2000. p. 357-379.

BROOKHOUSE, M. T. Eucalypt dendrochronology: past, present and potential. Australian Jounal of Botany, Victoria, v. 54, n. 5, p. 435-449, 2006.

BULCKEA, J. V. D.; WERNERSSONB, E. L. G.; DIERICKC, M.; LOOC, D. V. 3D tree-ring analysis using helical X-ray tomography. Dendrochronologia, Heildelberg, v. 32, n. 1, p. 39-46, 2014.

CALLADO, C. H.; GUIMARÃES, R. C. Estudo dos anéis de crescimento de Schizolobium parahyba (Leguminosae: Caesalpinioideae) após episódio de mortalidade em Ilha Grande, Rio de Janeiro. Revista Brasileira de Botânica, São Paulo, v. 33, n. 1, p. 84-91, 2010.

CALLADO, C. H.; ROIG, F. A.; TOMAZELLO FILHO, M.; BARROS, C. F. Cambial growth periodicity studies of South American woody species - a review. IAWA Journal, Leiden, v. 34, n. 3, p. 213-230, 2013. 
CALLADO, C. H.; VASCONCELLOS, T. J. ; COSTA, M. S.; BARROS, C. F.; ROIG, F. A.; TOMAZELLO FILHO, M. Studies on cambial activity: advances and challenges in the knowledge of growth dynamics of Brazilian woody species. Anais da Academia Brasileira de Ciências, v. 86, p. 277-284, 2014.

CARLQUIST, S. Further concepts in ecological wood anatomy, with comments on recent work in wood anatomy and evolution. Aliso, Clarelmont, v. 9, p. 499-553, 1980.

CASTRO, V. R. Aplicação de métodos não destrutivos na avaliação das propriedades físicas do lenho de árvores de Pinus caribaea var. hondurensis e Tectona grandis. 2011. 106 p. Dissertação (Mestrado em Recursos Florestais) - Escola Superior de Agricultura "Luiz de Queiroz". Universidade de São Paulo, Piracicaba, SP.

CASTRO, V. R.; SURDI, P. G.; TOMAZELLO FILHO, M. Avaliação do perfil radial do lenho de árvores de Pinus caribaea var. hondurensis por densitometria de raios X. Scientia Forestalis, Piracicaba, v. 42, n. 103, p. 353-360, 2014.

CASTRO, V. R.; TOMAZELLO FILHO, M.; ARIZAPANA, M. A.; SILVA, J. C.; SILVA FILHO, D. F.; POLIZEL, J. L. Avaliação do perfil radial do lenho de árvores de teca (Tectona grandis), através da tomografia de impulso. Floresta e Ambiente, Seropédica, v. 18, n. 2, p. 144-152, 2011.

CHAGAS, S. F.; EVANGELISTA, W. V.; SILVA, J. C.; PINHEIRO, M. A. Estudo da retenção e penetração de CCA na madeira de teca, visando uso como mourões tratados. Scientia Forestalis, Piracicaba. v. 43, n. 105, p. 155165, 2015.

COSTA, M. S.; FERREIRA, K. E. B.; BOTOSSO, P. C.; CALLADO, C. H. Growth analysis of five Leguminosae native tree species from a seasonal semidecidual lowland forest in Brazil. Dendrochronologia, Verona, v. 36, p. 23-32, 2015.

CURY, G. Descrição da estrutura anatômica do lenho e sua aplicação na identificação de espécies arbóreas do Cerrado e da Mata Atlântica do estado de São Paulo. 2002. 125 p. Dissertação (Mestrado em Recursos Florestais) - Escola Superior de Agricultura "Luiz de Queiroz" - Universidade de São Paulo, Piracicaba, 2002.

DÜNISCH, O.; BAUCH, J; GASPAROTTO, L. Formation of increment zones and intraannual growth dynamics in the xylem of Swietenia macrophylla, Carapa guianensis, and Cedrela odorata. IAWA Journal, Leiden, v. 23, n. 2, p. 101-119, 2002.

DÜNISCH, O.; MONTÓIA, V. R. EBAUCH, J. Dendroecological investigations on Swietenia macrophylla and Cedrela odorata in the central Amazon. Trees, New York, v. 17, n. 3, p. 244-250, 2003.

FERREIRA, A. T. B.; TOMAZELLO FILHO, M. Characterization of tree-rings of Pinus caribaea var. hondurensis trees by X ray densitometry. Scientia Forestalis, Piracicaba, v. 37, n. 83, p. 287-298, 2009.

HUAMAN-CALDERÓN, C. I. Dendrocronologia de árboles de Hymenaea courbaril en la región de Madre de Dios, Peru. 2011. 113 p. Dissertação (Mestrado em Bosques e Gestão de Recursos Florestais) - Universidade Nacional Agraria La Molina, Lima, 2011.

IAWA - International Association of Wood Anatomy. List of microscopic features for wood identification. IAWA Bulletin, Leiden, v. 10, n. 3, p. 226-332, 1989.

IBAMA - INSTITUTO BRASILEIRO DO MEIO AMBENTE E DOS RECURSOS NATURAIS RENOVÁVEIS. Normas de procedimentos em estudos de anatomia de madeira: I. Angiospermae, II. Gimnospermae. Brasília, 1991. 19 p. 
JACOBY, G. C. Overview of tree-ring analysis in tropical regions. IAWA bulletin new series, v. 10, p. 99$108,1989$.

KNAPIC, S.; PIRRALHO, M.; LOUZADA, J. L.; PEREIRA, H. Early assessment of density features for 19 Eucalyptus species using X-ray microdensitometry in a perspective of potential biomass production. Wood Science and Technology, New York, v. 48, n. 1, p. 37-49, 2014.

KOUBAA, A.; ZHANG, S. Y. T.; MAKNI, S. Defining the transition from earlywood to latewood in black spruce based on intra-ring wood density profiles from X-ray densitometry. Annals of Forest Science, Nancy, v. 59, n. 5-6, p. 511-518, 2002.

KROMER, B. Radiocarbon and dendrochronology. Dendrochronologia, Heidelberg, v. 27, n. 1, p. 15$19,2009$.

LATORRACA, J. V. F.; SOUZA, M. T.; SILVA, L. D.; RAMOS, L. M. Dendrocronologia de árvores de Schizolobium parahyba de ocorrência na Rebio de Tinguá-RJ. Revista Árvore, Viçosa, v. 39, n. 2, p. 385-394, 2015.

LISI, C. S.; PESSENDA, L. C. R.; TOMAZELLO FILHO, M.; ROZANSKI, K. 14C bomb effect in tree rings of tropical and subtropical species of Brazil. Tree Ring Research, Arizona, v. 57, n. 2, p. 191-196, 2001.

LISI, C. S.; TOMAZELLO FILHO, M.; BOTOSSO, P. C.; ROIG, F. A.; MARIA, V. R. B.; FERREIRA-FEDELE, L.; VOIGT, A. R. A. Tree-ring formation, radial increment periodicity an phenology oh three species from a seasonal semi-deciduous forest in southeast Brazil. IAWA Journal, Leiden, v. 29, n. 2, p. 189-207, 2008.

LOBÃO, M. S. Dendrocronologia, fenologia, atividade cambial e qualidade do lenho de árvores de Cedrela odorata L., Cedrela fissilis Vell. e Schizolobium parahyba var. amazonicum no estado do Acre, Brasil. 2011. 209 p. Tese. (Doutorado em Recursos Florestais) - Escola Superior de Agricultura "Luiz de Queiroz. Universidade de São Paulo, Piracicaba, 2011.

LOBÃO, M. S.; COSTA, D. P.; ALMONACID, M. A. A.; TOMAZELLO FILHO, M. Qualidade do lenho de árvores de Schizolobium parahyba var. amazonicum no estado do Acre. Floresta e Ambiente, Seropédica, v. 19, n. 3, p. 374-384, 2012.

LONGUI, E. L.; COSTA, N. O.; CIELO FILHO, R.; MARCATI, C. R.; ROMEIRO, D.; RAJPUT, K.S.; LIMA, I. L.; FLORSHEIM, S. M. Wood and leaf anatomy of Copaifera langsdorffii dwarf trees. IAWA Journal, Leiden, v. 35, n. 2, p. 170-185, 2014.

LOURFY, M. H. Wood anatomy and its implications on the taxonomy of Apollonias nees (Lauraceae). Journal of Botanical Taxonomy and Geobotany. v. 120, p. 75-90, 2009.

LUCHI, A. E. Periodicidade de crescimento em Hymeneae courbaril L. e anatomia ecológica do lenho de espécies de mata ciliar. 1998. 236 p. (Doutorado em Botânica) - Universidade de São Paulo, São Paulo, 1998.

MAINIERI, C.; CHIMELO, J. P. Fichas de características das madeiras brasileiras. São Paulo: Instituto de Pesquisas Tecnológicas do Estado de São Paulo S.A. - IPT, 1989. 419 p.

MAINIERI, C.; CHIMELO, J. P.; ALFONSO, V. A. Manual de identificação das principais madeiras comerciais brasileiras. São Paulo: Promocet, 1983.

MARCATI, C. R.; ALFONSO, V. A.; BENETATI, L. Anatomia comparada do lenho de Copaifera langsdorffi Desf. (Leguminosae-Caesalpinoideae) de floresta e cerradão. Revista Brasileira de Botânica, São Paulo, v. 24, n. 3, p. 311-320, 2001. 
MARCATI, C. R.; ANGYALOSSY, V.; EVERT, R. F. Seasonal variation in wood formation of Cedrela fissilis (Meliaceae). IAWA Journal, Leiden, v. 27, n. 2, p.199-211, 2006a.

MARCATI, C. R.; MILANEZ, C. R. D.; MACHADO, S. R. Seasonal development of secondary xylem and phloem in Schizolobium parahyba (Leguminosae: Caesalpinioideae). Trees, New York, v. 22, n. 1, p. 3-12, 2008.

MARCATI, C. R.; OLIVEIRA, J. S.; MACHADO, S. R. Growth rings in cerrado woody species: occurrence and anatomical markers. Biota Neotropica, Campinas, v. 6, n. 3, p. 1-31, 2006b.

MEDEIROS, J. G. S.; TOMAZELLO FILHO, M.; KRUG, F. J.; VIVES, A. E. Tree-ring characterization of Araucaria columnaris and its applicability as a lead indicator in environmental monitoring. Dendrochronologia, Amsterdam, v. 26, n. 3, p. 165-171, 2008.

MOTHE, F.; SCIAMA, D.; LEBAN, M.; NEPVEU, G. Localisation de la transition bois initial-bois final dans un cerne de chêne par analyse microdensitométrique. Annals of Forest Science, Nancy, v. 55, n. 4, p. 437 $449,1998$.

MOZETO, A. A.; FRITZ, P.; MOREIRA, R. Z.; VETTER, R.; ARAVENA, R.; SALATI, E.; DRIMMIE, R. J. Growth rates of natural Amazonian forest trees based on radiocarbon measurements. Radiocarbon, v. 30, n. 1, p. $1-6,1988$.

MOYA, R.; TOMAZELLO FILHO, M. Wood density variation and tree ring demarcation in Gmelina arborea trees using X-ray densitometry. Cerne, Lavras, v. 15, n. 1, p. 92-100, 2009.

NOCETTI, M.; ROZENBERG, P.; CHAIX, G.; MACCHIONI, N. Provenance effect on the ring structure of teak (Tectona grandis L.f.) wood by X-ray microdensitometry. Annals of Forest Science, Nancy, v. 68, n. 8, p. 13751383, 2011.

OLIVEIRA, B. R. O.; LATORRACA, J. V. F.; TOMAZELlO FILHO, M.; PALERMO, G. P. M.; NASCIMENTO, A. M.; PASTRO, M. S. X-ray microdensitometry applied to determination of wood density variation of Eucalyptus grandis trees. Scientia Forestalis, Piracicaba, v. 40, n. 93, p. 103-112. 2012.

OLIVEIRA, B. R. O.; LATORRACA, J. V. F.; TOMAZELLO FILHO, M.; GARCIA, R. A.; CARVALHO, A. M. Correlações dendroclimatológicas do Eucalyptus grandis na região de Rio Claro, RJ. Ciência Florestal, Santa Maria, v. 21, n. 3, p. 495-504, 2011.

OLIVEIRA, I. R. Avaliação do crescimento e da qualidade do lenho de árvores de Cariniana legalis submetidas a diferentes espaçamentos. 2015. 118 p. Dissertação (Mestrado em Recursos Florestais) - Escola Superior de Agricultura "Luiz de Queiroz". Universidade de São Paulo, Piracicaba. 2015.

OLIVEIRA, J. M. Anéis de crescimento de Araucaria angustifolia (Bertol.) O. Kuntze: bases de dendroecologia em ecossistemas subtropicais montanhosos no Brasil. 2007. 139 p. Doutorado (Doutorado em Ecologia) - Universidade Federal do Rio Grande do Sul. Porto Alegre, 2007.

OLIVEIRA, J. M.; SANTAROSA, E.; PILLAR, V. D.; ROIG, F. A. Seasonal cambium activity in the subtropical rain forest tree Araucaria angustifolia. Trees, New York, v. 23, n. 1, p. 107-115, 2009.

OLIVEIRA, J. M.; SANTAROSA, E.; ROIG, F. A. Amostragem temporal de anéis de crescimento: uma alternativa para determinar ritmo de atividade cambial. Revista Brasileira de Biociências, Porto Alegre, v. 5, Supl. 1, p. 615-617, 2007. 
PALERMO, G. P. M.; LATORRACA, J. V. F.; ABREU, H. S. Métodos e técnicas de diagnose de identificação dos anéis de crescimento de árvores tropicais. Floresta e Ambiente, Seropédica, v. 9, n. 1, p. 165-175, 2002.

PARKER, M. L.; W. HENOCH, E. S. The use of Engelmann spruce latewood density for dendrochronological purposes. Canadian Journal of Forest Research, Ottawa, v. 1, n. 2, p. 90-98, 1971.

POLGE, H. Fifteen years of wood radiation densitometry. Wood Science and Technology, Berlin, v. 12, n. 3, p. $187-196,1978$.

POLGE, H. The use of $\mathrm{x}$-ray densitometric methods in dendrochronology. Tree-Ring Bulletin, Tucson, v. 30, p. $1-10,1970$.

PUMIJUMNONG, N.; ECKSTEIN, D.; SASS, U. Tree-ring research on Tectona grandis in Northern Thailand. Iawa Journal, Leiden, v. 16, n. 4, p. 385-392, 1995.

RAHMAN, M. M.; FUJIWARA, S.; HIRAKAWA, Y.; KANAGAWA, Y. Wood density in relation to growth rate and tissue proportions of teak, Tectona grandis, grown in Bangladesh. Agris, Roma, v. 10, 2004.

RAM, S.; BORGAONKAR, H. P.; SIKDE, A. B. Tree-ring analysis of teak (Tectona grandis L.f.) in central India and its relationship with rainfall and moisture index. Journal of Earth System Sciences, v. 117, p. 637-645, 2008.

ROIG, F. A. Dendrocronología en lós bosques del Neotrópico: revisión y porspección futura. In: ROIG, F. A. (Org.) Dendrocronología em América Latina. Mendoza: EDIUNC, 2000. p. 307-355.

SANTOS, G. M.; LINARES, R.; LISI. C. S.; TOMAZELLO FILHO, M. Annual tree-growth rings in a wood sample of Araucaria angustifolia tree: towards improving the ${ }^{14} \mathrm{C}$ calibration curve for the Southern Hemisphere. Quaternary Geochronology, v. 25, p. 96-103, 2015.

SCHIPPER-GUEROVICH, A. Dendrocronología del cedro Cedrela odorata L. (Meliaceae) de la amazonia súr del Perú, la región Madre de Dios. 2011. Dissertação (Mestrado em Bosques y Gestion de Recursos Forestales) - Universidad Nacional Agraria La Molina. Lima, 2011.

SCHWEINGRUBER, F. H. Tree Rings and Environment Dendroecology. Paul Haupt Editors, 1996. 609 p.

SONSIN, J. O.; GASSON, P. E.; BARROS, C. F.; MARCATI, C. R. A comparison of the wood anatomy of 11 species from two cerrado habitats. Botanical Journal of the Linnean Society, v. 170, n. 2, p. 257-276, 2012.

TOMAZELLO FILHO, M.; BOTOSSO, P. C.; LISI, C. S. Potencialidade da família Meliaceae para dendrocronologia em regiões tropicais e subtropicais. In: ROIG, F. A. (Org.). Dendrocronologia en América Latina. Mendonza: EDIUNC, 2000. p. 381-431.

TOMAZELLO FILHO, M.; BOTOSSO, P. C.; LISI, C. S.; SPATHELF, P. Cedrela angustifolia Ses. et Moc. ex Dc., Meliaceae: potential species for tropical dendrochronology. Palaeobotanist, Lucknow, v. 50, p. 47-53, 2001.

TOMAZELLO FILHO, M.; BRAZOLIN, S.; CHAGAS, M. P.; OLIVEIRA, J. T. S.; BALLARIN, A. W.; BENJAMIN, C. A. Application of X-ray technique in nondestructive evaluation of Eucalypt wood. Maderas: Ciência y Tecnologia, Concepción, v. 10, n. 2, p. 139-145, 2008.

TOMAZELLO FILHO, M.; LISI, C. S.; HANSEN, N.; CURY, G. Anatomical features of increment zones in different tree species in the State of São Paulo, Brazil. Scientia Forestalis, Piracicaba, n. 66, p. 46-55, 2004. 
Albuquerque et al. - Comparative analysis of anatomy and microdensitometry

of the growth rings of hardwoods and conifers, with emphasis on dendrochronology

TREVIZOR, T. T. Anatomia comparada do lenho de 64 espécies arbóreas de ocorrência natural na floresta tropical Amazônica no estado do Pará. 2011. 214 p. Dissertação (Mestrado em Recursos Florestais) - Escola Superior de Agricultura "Luiz de Queiroz". Universidade de São Paulo. Piracicaba, 2011.

UGOLINO, B.; LATORRACA, J. V. F.; TOMAZELLO FILHO, M. Tree-ring growth response of Tectona grandis trees to climatic variables in central-region of Brazil. Scientia Forestalis, Piracicaba, v. 42, n. 104, p. 473$482,2014$.

WEHR, N. J.; TOMAZELlO FILHO, M. Caracterização dos anéis de crescimento de árvores de Araucaria angustifolia através da microdensitometria de raios X. Scientia Forestalis, Piracicaba, n. 58, p. 161-170, 2000.

WHITE, C. Comparison of maximum density analysis and ring width measurement: applications in dendroclimatology. 2010. 93 p. Thesis (Department of Geography and Environment) - Mount Allison University, New Brunswick, 2010.

Recebido em 27/11/2014

Aceito para publicação em 27/01/2016 